\title{
Efficiency of Intravenous Thrombolytic Therapy in Isolated Middle Cerebral Artery Occlusions: A Computed Tomography Angiography Study
}

\author{
İzole Orta Serebral Arter Oklüzyonlarında İntravenöz Trombolitik Tedavinin Yeri: \\ Bilgisayarlı Tomografi Anjiyografi Çalışması
}

\author{
(1) Ezgi Sezer Eryıldız, (1) Atilla Özcan Özdemir \\ Eskisehir Osmangazi University Faculty of Medicine, Department of Neurology, Eskisehir, Turkey
}

\begin{abstract}
Objective: We aimed to evaluate the outcomes of two groups of patients with acute ischemic stroke who were treated with intravenous recombinant tissueplasminogen activator (IV rt-PA); those with isolated middle cerebral artery (MCA) occlusion and those without any large vessel occlusion.

Materials and Methods: Data of patients treated with IV rt-PA within 4.5 hours of symptom onset between March 2015 and January 2017 were retrospectively analyzed. Patients were divided into two groups; those with isolated MCA occlusion and those with no large vessel occlusion. Large vessel occlusion was detected with contrast-enhanced computed tomography angiography performed before IV rt-PA. Additionally, demographic and clinical data of the patients were analyzed. The clinical outcomes of the patients were determined using the modified Rankin Scale (mRS) score at 3 months after treatment.

Results: A total of 69 patients were included in the study. Isolated MCA occlusion was observed in $28(40.6 \%)$ patients. The rate of very good outcome (mRS $0-1)$ was $46.4 \%$, whereas the rate of poor outcome (mRS 3-6) was $42.9 \%$ in the group with isolated MCA occlusion. Moreover, in the other group, the rate of very good outcome and poor outcome were $65.9 \%$ and $26.8 \%$, respectively.

Conclusion: In acute ischemic stroke with isolated MCA occlusion, due to the favorable outcomes of the patients, IV rt-PA continues to be the best treatment option in cases where endovascular treatment options cannot be performed and it should be applied by physicians in appropriate cases without delay.
\end{abstract}

Keywords: Acute stroke, middle cerebral artery, occlusion, intravenous recombinant tissue-plasminogen activator, outcome

$\ddot{\mathbf{O z}}$

Amaç: İntravenöz rekombinant doku-plazminojen aktivatörü (IV rt-PA) uygulanan akut iskemik inme hastalarında izole orta serebral arter (OSA) oklüzyonu olan ve herhangi bir büyük damar oklüzyonu olmayan iki grubun tedavi yanıtlarını ve sonlanımlarını değerlendirmeyi amaçladık.

Gereç ve Yöntem: İnme merkezimizde Mart 2015-Ocak 2017 tarihleri arasında semptom sonrası ilk 4,5 saat içerisinde IV rt-PA uygulanan hastaların verileri, izole OSA oklüzyonu olanlar ve herhangi bir büyük damar oklüzyonu olmayanlar olarak ikiye ayrılarak retrospektif olarak analiz edildi. Büyük damar oklüzyonu; IV rt-PA öncesi yapılan kontrastlı bilgisayarlı tomografi anjiyografi ile saptandı. Bunun yanında hastaların demografik ve klinik verileri değerlendirildi. Hastaların klinik sonlanımları ise tedavinin 3. ayında hesaplanan 'the modified Rankin Scale' (mRS) skorları ile belirlendi.

Bulgular: Toplam 69 hasta çalışmaya dahil edilmiş olup, bunların 28'inde $(\% 40,6)$ izole OSA oklüzyonu saptandı. İzole OSA oklüzyonu olan grupta çok iyi sonlanım (mRS 0-1) oranı \% 46,4 bulunurken, kötü sonlanım (mRS 3-6) oranı \%42,9 olarak bulundu. Herhangi bir büyük damar oklüzyonu olmayan grupta ise çok iyi sonlanım oranı $\% 65,9$ bulunurken, kötü sonlanım oranı $\% 26,8$ olarak bulundu.

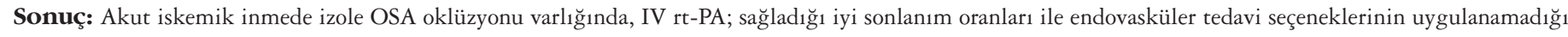
durumlarda en iyi tedavi seçeneği olmayı sürdürmektedir ve uygun hastalarda klinisyen tarafından vakit kaybetmeksizin uygulanmalıdır.

Anahtar Kelimeler: Akut inme, orta serebral arter, oklüzyon, intravenöz rekombinant doku-plazminojen aktivatörü, sonlanım

Address for Correspondence/Yazışma Adresi: Ezgi Sezer Eryıldız MD, Eskisehir Osmangazi University Faculty of Medicine, Department of Neurology, Eskisehir, Turkey Phone: +90 5057954535 E-mail: ex-gi@hotmail.com ORCID ID: orcid.org/0000-0002-9653-3009

Received/Geliş Tarihi: 27.04.2017 Accepted/Kabul Tarihi: 18.08.2017

${ }^{\circ}$ Copyright 2018 by Turkish Neurological Society

Turkish Journal of Neurology published by Galenos Publishing House. 


\section{Introduction}

Intravenous recombinant tissue plasminogen activator (IV rtPA) is a valuable and approved treatment in acute ischemic stroke $(1,2)$. Worldwide, $80 \%$ of ischemic strokes are caused by arterial occlusion and $50 \%$ are caused by large vessel occlusion $(3,4,5)$. However, studies on the efficacy of IV rt-PA according to the site of occlusion are insufficient. Larger clot load and greater proximal occlusion due to large vessel occlusion are related with low efficacy of IV rt-PA and a worse outcome $(6,7,8,9)$.

The current evidence shows recanalization and reperfusion of the affected vascular territory result in better outcomes and we have to aim to achieve higher rates of recanalization treatment (10). Prediction of response to IV rt-PA in large vessel occlusions is important in the selection of patients for mechanical thrombectomy and endovascular treatment (11).

We aimed to compare the treatment results and outcomes of two patient groups to which we gave IV rt-PA treatment alone, involving patients with isolated middle cerebral artery (MCA) occlusion and those with no large vessel occlusion in our stroke center.

\section{Materials and Methods}

Patients who received IV rt-PA within 4.5 hours of symptom onset between March 2015 and January 2017 were included in our study and were analyzed retrospectively. Intravenous rt-PA was given at a dose of $0.9 \mathrm{mg} / \mathrm{kg}$ (maximum $90 \mathrm{mg}$ ) according to the guideline of the European Stroke Organization. Contrast enhancing computed tomography angiography (CTA) was performed to all patients besides cranial CT before giving IV rt-PA. Complete loss of signal distal of the occluded area in CTA was defined as vessel occlusion. Large vessel occlusion was defined as occlusion of one of these arteries detected using CTA before IV rt-PA: Internal carotid artery (ICA), first segment (M1) or proximal of the second segment (M2) of the MCA, first segment (A1) of the anterior cerebral artery, first segment (P1) of the posterior cerebral artery, basilar artery or last segment (V4) of the vertebral artery (VA) (Figure 1). Angiographic data were evaluated by 2 neurologists. Patients with other large vessel occlusions besides occlusion of MCA, with tandem ICA and MCA occlusion, in whom CTA was not performed and to whom endovascular treatment was performed following IV rt-PA were excluded. National Institutes of Health Stroke Scale (NIHSS) scores before and 24 hours after treatment, demographic data, medical history, and duration between the beginning of symptoms and treatment were evaluated. The modified Rankin Scale (mRS) scores 3 months after treatment were measured. mRS scores $0-1$ are defined as very good outcome, $0-2$ as good outcome, and 3-6 as poor outcome.

The study was approved by the Eskisehir Osmangazi University Faculty of Medicine of Local Ethics Committee (protocol number: 80558721/G-267).

\section{Statistical Analysis}

The features of the patients given IV rt-PA who had isolated MCA occlusion and those who had no large vessel occlusion before and after treatment were analyzed. Continuous data are given as means and medians and categorical data are given as percentages. IBM SPSS Statistics 21.0 (IBM Corp. Released 2012. IBM SPSS
Statistics for Windows, Version 21.0. Armonk, NY: IBM Corp.) was used for analysis.

\section{Results}

Sixty-nine patients with a diagnosis of acute ischemic stroke who were given IV rt-PA and underwent CTA before treatment were included in the study. Isolated MCA occlusion was found in $28(40.6 \%)$ patients. M1 occlusion was found in 24 of these 28 patients, and M2 occlusion was found in 4. Very good outcome was observed in $40(58 \%)$ patients, good outcome was seen in 46 $(66.7 \%)$ patients, and $23(33.3 \%)$ patients had poor outcomes. Six $(8.7 \%)$ patients died (Table 1$)$.

In patients with isolated MCA occlusion, the median NIHSS score at admission was 12.5, whereas it was 6 at 24 hours after treatment. At 24 hours after the treatment, $\geq 4$ points improvement in NIHSS scores were achieved in $46.4 \%$ of patients, and $\geq 8$ points improvement was seen in $25 \%$ of patients. At the $3^{\text {rd }}$ month, very

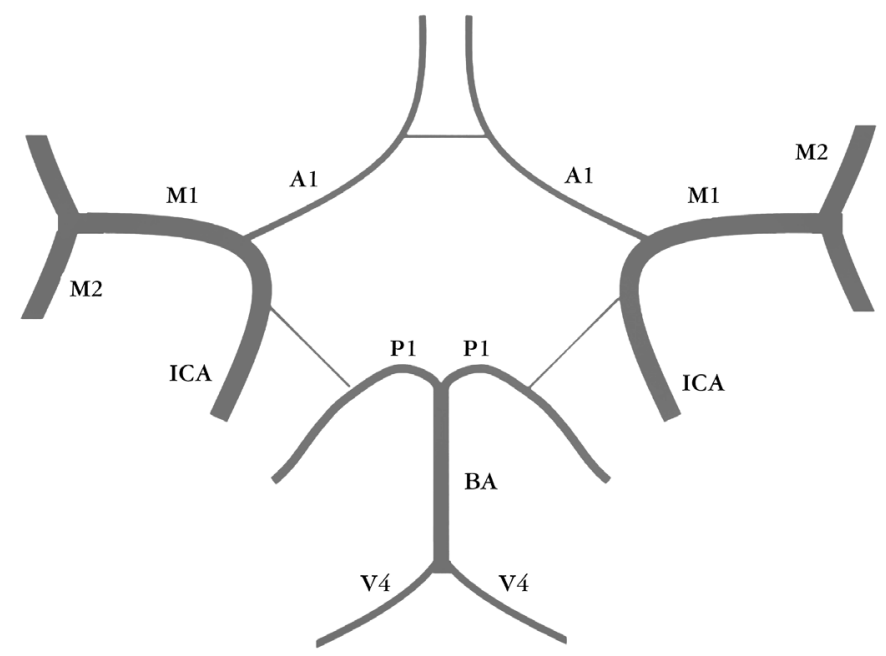

Figure 1. Large vessel occlusion areas

ICA: Internal carotid artery, A1: First segment of the anterior cerebral artery, $M 1$ and M2: First and second segments of the middle cerebral artery, P1: First segment of the posterior cerebral artery, BA: Basilar artery, V4: Last segment of vertebral artery

Table 1. Features of the patients before and after intravenous recombinant tissue-plasminogen activator

\begin{tabular}{lc|} 
Features & $\mathrm{n}=69$ \\
Large vessel occlusion, n (\%) & $28(40.6)$ \\
MCA M1 & $24(34.8)$ \\
MCA M2 & $4(5.8)$ \\
Very good outcome (mRS 0-1), n (\%) & $40(58)$ \\
Good outcome (mRS 0-2), n (\%) & $46(66.7)$ \\
Poor outcome (mRS 3-6), n (\%) & $23(33.3)$ \\
Mortality, n (\%) & $6(8.7)$ \\
$\begin{array}{l}\text { MCA: Middle cerebral artery, M1 and M2: First and second segments of the } \\
\text { middle cerebral artery, mRS: Modified Rankin Scale }\end{array}$ \\
\hline
\end{tabular}


good outcome was achieved in $46.4 \%$ of patients, good outcome was found in $57.1 \%$, and $42.9 \%$ had poor outcomes. The mortality rate was $10.7 \%$. Other demographic and clinical features of the patients with isolated MCA occlusion are shown in Table 2.

The patients with no large vessel occlusion had median NIHSS scores of 9 and 3 before and 24 hours after treatment, respectively. At 24 hours after treatment, $\geq 4$ points improvement in NIHSS scores were achieved in $73.2 \%$ of patients, and in $\geq 8$ points improvement in $34.1 \%$. At the 3 rd month, very good outcome was observed in $65.9 \%$ of patients, good outcome in $73.2 \%$, and $26.6 \%$ had poor outcomes. The mortality rate was $7.3 \%$. Other demographic and clinic features of the patients with no large vessel occlusion are shown in Table 3.

\section{Discussion}

It is well established that IV rt-PA improves the clinical outcomes of patients with acute ischemic stroke $(1,2)$. However, it is thought that recanalization rates are lower and outcomes are worse in patients with large vessel occlusions $(12,13)$. Therefore, it is important to reveal the treatment responses to IV rt-PA in large vessel occlusions to lead patients to endovascular treatment. In our study, we found that the rate of isolated MCA occlusion was $40.6 \%$ in CTA in patients who were given IV rt-PA in the first 4.5 hours.

Table 2. Features of the patients with isolated middle cerebral artery occlusion before and after intravenous recombinant tissue-plasminogen activator

$\begin{array}{lc}\text { Features } & \mathbf{n}=28 \\ \text { Male, n (\%) } & 12(42.9) \\ \text { Age, mean (SD) } & 65.4(12.5) \\ \text { Beginning of symptom-treatment (minute), } & 178.1(64.1) \\ \text { mean (SD) } & 12.5(6) \\ \text { NIHSS score at admission, median (IQR) } & 6(13) \\ \text { 24th hour NIHSS score, median (IQR) } & 13(46.4) \\ \geq 4 \text { points improvement in NIHSS scores at 24 } & 7(25) \\ \text { hours, n (\%) } & \\ \geq 8 \text { points improvement in NIHSS scores at 24 } & \\ \text { hours, n (\%) } & 20(71.4) \\ \text { Vascular risk factors, n (\%) } & 7(25) \\ \quad \text { Hypertension } & 10(35.7) \\ \quad \text { Diabetes mellitus } & 8(28.6) \\ \quad \text { Hyperlipidemia } & 3(10.7) \\ \quad \text { Atrial fibrillation } & 7(25) \\ \quad \text { Previous stroke } & 13(46.4) \\ \text { Cigarette smoking } & 16(57.1) \\ \text { Very good outcome (mRS 0-1), n (\%) } & 12(42.9) \\ \text { Good outcome (mRS 0-2), n (\%) } & 3(10.7) \\ \text { Poor outcome (mRS 3-6), n (\%) } & \\ \text { MD: Standard deviation, NIHSS: The National Institutes of Health Stroke Scale, } \\ \text { IQR: Interquartile range, mRS: Modified Rankin Scale }\end{array}$

In another study performed with a similar number of patients, the rate of large vessel occlusion was $52.1 \%$ in CTA. However, in that study, patients were evaluated in terms of large vessel occlusion in the first 8 hours and the rate decreased if CTA was performed earlier (14). In both that study and the present study, the M1 segment of the MCA was the most affected artery. In our study, we excluded patients with occlusion in a large vessel other than isolated MCA such as basilar artery, terminal or tandem ICA and MCA because endovascular treatment was performed alone or following IV rt-PA in such occlusions, which could contribute to a higher rate in our study.

In previous studies, $52.4 \%$ of the patients who received IV rt$\mathrm{PA}$ in the first 4.5 hours had a good outcome, which was defined as having 0-1 mRS scores (2). In our study, the percentage of patients with $0-1 \mathrm{mRS}$ was $58 \%$. The percentage of $0-1 \mathrm{mRS}$ was $46.4 \%$ in patients with isolated MCA occlusion with no other large vessel occlusion and was $65.9 \%$ in patients with no large vessel occlusion. The rate of poor outcome was higher in patients with isolated MCA occlusion compared with the other groups. In the Stroke Prevention Trial in Sickle Cell Anemia, large vessel occlusion detected in CTA was found to be an independent predictor of poor outcome (15). In the same study, patients with $\geq 10$ NIHSS scores and occlusion in the anterior circulation such as the MCA or the terminal of the ICA had 12-fold worse outcomes.

Table 3. Features of the patients with no large vessel occlusion before and after intravenous recombinant tissueplasminogen activator

$\begin{array}{lc}\text { Features } & \mathrm{n}=41 \\ \text { Male, n (\%) } & 25(61) \\ \text { Age, mean (SD) } & 60.5(10.9) \\ \begin{array}{l}\text { Beginning of symptom-treatment (minute), mean } \\ \text { (SD) }\end{array} & 163(53.9) \\ \text { NIHSS score at admission, median (IQR) } & 9(7) \\ \text { 24th hour NIHSS score, median (IQR) } & 3(8) \\ \geq 4 \text { points improvement in NIHSS scores at 24 } & 30(73.2) \\ \text { hours, n (\%) } & 14(34.1) \\ \geq 8 \text { points improvement in NIHSS scores at 24 } & \\ \text { hours, n (\%) } & \\ \text { Vascular risk factors, n (\%) } & 22(53.7) \\ \quad \text { Hypertension } & 9(22) \\ \quad \text { Diabetes mellitus } & 10(24.4) \\ \quad \text { Hyperlipidemia } & 9(22) \\ \quad \text { Atrial fibrillation } & 4(9.8) \\ \quad \text { Previous stroke } & 16(39) \\ \text { Cigarette smoking } & 27(65.9) \\ \quad \text { Very good outcome (mRS 0-1), n (\%) } & 30(73.2) \\ \text { Good outcome (mRS 0-2), n (\%) } & 11(26.8) \\ \text { Poor outcome (mRS 3-6), n (\%) } & 3(7.3) \\ \text { SD: Standart deviation, NIHSS: The National Institutes of Health Stroke Scale, } \\ \text { IQR: Interquartile range, mRS: Modified Rankin Scale }\end{array}$


The poor outcomes were supposed to be caused by greater clot load and more proximal occlusion (7). In another study, the rate of successful recanalization was found as $21 \%$ in patients who were given IV rt-PA and had large vessel occlusion (12). Ongoing collateral circulation could lead to good outcomes despite unsuccessful recanalization. This could have contributed to the better outcome rates in patients with large vessel occlusion in our study (16). In recent years, endovascular treatment has been shown to be useful when used in addition to IV rt-PA in acute stroke in large vessel occlusion. Trials such as the Multicenter Randomized Clinical Trial of Endovascular Treatment for Acute Ischemic Stroke in the Netherlands, Endovascular Treatment for Small Core and Anterior Circulation Proximal Occlusion with Emphasis on Minimizing CT to Recanalization Times and Extending the Time for Thrombolysis in Emergency Neurological Deficits-IntraArterial showed better recanalization rates and better outcomes with combined therapy $(17,18,19,20)$. Therefore, it is important to recognize patients earlier who could benefit from endovascular treatment and refer them to related centers as quickly as possible. However, it is important not to miss the chance of giving IV rtPA and according to the current guidelines, physicians should do their best to perform IV rt-PA without losing time (21). Rapid detection of large vessel occlusion is important and CTA in acute stroke is a widely-used reliable and fast modality $(14,15,22)$. Trials searching endovascular approach in acute stroke with intracranial large vessel occlusion include having $\geq 8$ NIHSS scores as a criterion besides non-invasive imaging suggestive of large vessel occlusion because higher NIHSS scores are related with large vessel occlusions $(23,24,25,26)$. In our study, NIHSS scores were higher in patients with large vessel occlusion compared with other patients. When we consider the fact that number of centers that can apply endovascular treatment is limited, the results of our study suggest that IV rt-PA is a good treatment choice in acute stroke with isolated MCA occlusion with very good outcomes in $46.4 \%$ of patients and good outcomes in $57.1 \%$ of patients.

\section{Study Limitations}

Retrospective and non-randomized nature of our study is its most limiting feature. Also, we had a small cohort and our study was performed in one center. Multi-center, prospective and randomized studies with larger numbers patients can give more precise results. In addition, the results of the efficacy of IV rt-PA could be different if patients with all large vessel occlusions such as basilar artery, terminal or tandem ICA and MCA were included. Despite these limitations, the results of our study are similar to the results of larger studies.

\section{Conclusion}

Despite the low efficacy of IV rt-PA in acute ischemic stroke with isolated MCA occlusion, aside from endovascular treatment, IV rt-PA is still the best treatment and it should be performed without delay by physicians in appropriate patients, especially when other treatment options cannot be performed.

\section{Ethics}

Ethics Committee Approval: The study was approved by the Eskisehir Osmangazi University Local Ethics Committee (approval number: 80558721/G-267).
Informed Consent: Consent form was filled out by all participants.

Peer-review: Externally and internally peer-reviewed.

\section{Authorship Contributions}

Surgical and Medical Practices: A.Ö.Ö., E.S.E., Concept: A.Ö.Ö., E.S.E., Design: A.Ö.Ö., E.S.E., Data Collection or Processing: E.S.E., Analysis or Interpretation: E.S.E., Literature Search: A.Ö.Ö., E.S.E., Writing: E.S.E.

Conflict of Interest: No conflict of interest was declared by the authors.

Financial Disclosure: The authors declared that this study received no financial support.

\section{References}

1. National Institute of Neurological Disorders and Stroke rt-PA Stroke Study Group. Tissue plasminogen activator for acute ischemic stroke. N Engl J Med 1995;333:1581-1587.

2. Hacke W, Kaste M, Bluhmki E, Brozman M, Dávalos A, Guidetti D, Larrue V, Lees KR, Medeghri Z, Machnig T, Schneider D, von Kummer R, Wahlgren $\mathrm{N}$, Toni D; ECASS Investigators. Thrombolysis with alteplase 3 to 4.5 hours after acute ischemic stroke. N Engl J Med 2008;359:1317-1329.

3. Fieschi C, Argentino C, Lenzi GL, Sacchetti ML, Toni D, Bozzao L. Clinical and instrumental evaluation of patients with ischemic stroke within the first six hours. J Neuro Sci 1989;91:311-321.

4. del Zoppo GJ, Poeck K, Pessin MS, Wolpert SM, Furlan AJ, Ferbert A, Alberts MJ, Zivin JA, Wechsler L, Busse $\mathrm{O}$, et al. Recombinant tissue plasminogen activator in acute thrombotic and embolic stroke. Ann Neurol 1992;32:78-86.

5. Smith WS, Lev MH, English JD, Camargo EC, Chou M, Johnston SC, Gonzalez G, Schaefer PW, Dillon WP, Koroshetz WJ, Furie KL. Significance of large vessel intracranial occlusion causing acute ischemic stroke and TIA. Stroke 2009; 40:3834-3840.

6. Saqqur M, Uchino K, Demchuk AM, Molina CA, Garami Z, Calleja S, Akhtar N, Orouk FO, Salam A, Shuaib A, Alexandrov AV; CLOTBUST Investigators. Site of arterial occlusion identified by transcranial Doppler predicts the response to intravenous thrombolysis for stroke. Stroke 2007;38:948-954.

7. Tan IY, Demchuk AM, Hopyan J, Zhang L, Gladstone D, Wong K, Martin M, Symons SP, Fox AJ, Aviv RI. CT angiography clot burden score and collateral score: correlation with clinical and radiologic outcomes in acute middle cerebral artery infarct. AJNR Am J Neuroradiol 2009;30:525-531.

8. Linfante I, Llinas RH, Selim M, Chaves C, Kumar S, Parker RA, Caplan LR, Schlaug G. Clinical and vascular outcome in internal carotid artery versus middle cerebral artery occlusions after intravenous tissue plasminogen activator. Stroke 2002;33:2066-2071.

9. González RG, Lev MH, Goldmacher GV, Smith WS, Payabvash S, Harris GJ, Halpern EF, Koroshetz WJ, Camargo EC, Dillon WP, Furie KL. Improved outcome prediction using CT angiography in addition to standard ischemic stroke assessment: results from the STOPStroke study. PloS One 2012; 7:e30352.

10. Rha JH, Saver JL. The impact of recanalization on ischemic stroke outcome: a meta-analysis. Stroke 2007;38:967-973.

11. Matias-Guiu JA, López-Ibor L. Endovascular treatment for acute ischemic stroke: in search of evidence. Neurologia 2014;29:65-67.

12. Bhatia R, Hill MD, Shobha N, Menon B, Bal S, Kochar P, Watson T, Goyal M, Demchuk AM. Low rates of acute recanalization with intravenous recombinant tissue plasminogen activator in ischemic stroke: real-world experience and a call for action. Stroke 2010;41:2254-2258.

13. Smith WS, Tsao JW, Billings ME, Johnston SC, Hemphill JC, Bonovich DC, Dillon WP. Prognostic significance of angiographically confirmed large vessel intracranial occlusion in patients presenting with acute brain ischemia. Neurocrit Care 2006;4:14-17.

14. Matias-Guiu JA, Serna-Candel C, Espejo-Domínguez JM, FernándezMatarrubia M, Simal P, Matias-Guiu J. Large artery occlusion diagnosed by computed tomography angiography in acute ischaemic stroke: frequency, predictive factors, and safety. Neurologia 2014;29:261-266. 
15. González RG, Lev MH, Goldmacher GV, Smith WS, Payabvash S, Harris GJ, Halpern EF, Koroshetz WJ, Camargo EC, Dillon WP, Furie KL. Improved outcome prediction using $\mathrm{CT}$ angiography in addition to standard ischemic stroke assessment: results from the STOPStroke study. PloS One 2012;7:e30352.

16. Zhu W, Churilov L, Campbell BC, Lin M, Liu X, Davis SM, Yan B. Does large vessel occlusion affect clinical outcome in stroke with mild neurologic deficits after intravenous thrombolysis? J Stroke Cerebrovasc Dis 2014;23:28882893.

17. Berkhemer OA, Fransen PS, Beumer D, van den Berg LA, Lingsma HF, Yoo AJ, Schonewille WJ, Vos JA, Nederkoorn PJ, Wermer MJ, van Walderveen MA, Staals J, Hofmeijer J, van Oostayen JA, Lycklama à Nijeholt GJ, Boiten J, Brouwer PA, Emmer BJ, de Bruijn SF, van Dijk LC, Kappelle LJ, Lo RH, van Dijk EJ, de Vries J, de Kort PL, van Rooij WJ, van den Berg JS, van Hasselt BA, Aerden LA, Dallinga RJ, Visser MC, Bot JC, Vroomen PC, Eshghi O, Schreuder TH, Heijboer RJ, Keizer K, Tielbeek AV, den Hertog HM, Gerrits DG, van den Berg-Vos RM, Karas GB, Steyerberg EW, Flach HZ, Marquering HA, Sprengers ME, Jenniskens SF, Beenen LF, van den Berg R, Koudstaal PJ, van Zwam WH, Roos YB, van der Lugt A, van Oostenbrugge RJ, Majoie CB, Dippel DW; MR CLEAN Investigators. A randomized trial of intraarterial treatment for acute ischemic stroke. $\mathrm{N}$ Engl J Med 2015;372:11-20.

18. Goyal M, Demchuk AM, Menon BK, Eesa M, Rempel JL, Thornton J, Roy D, Jovin TG, Willinsky RA, Sapkota BL, Dowlatshahi D, Frei DF, Kamal NR, Montanera WJ, Poppe AY, Ryckborst KJ, Silver FL, Shuaib A, Tampieri D, Williams D, Bang OY, Baxter BW, Burns PA, Choe H, Heo JH, Holmstedt CA, Jankowitz B, Kelly M, Linares G, Mandzia JL, Shankar J, Sohn SI, Swartz RH, Barber PA, Coutts SB, Smith EE, Morrish WF, Weill A, Subramaniam S, Mitha AP, Wong JH, Lowerison MW, Sajobi TT, Hill MD; ESCAPE Trial Investigators. Randomized assessment of rapid endovascular treatment of ischemic stroke. N Engl J Med 2015;372:1019-1030.

19. Campbell BC, Mitchell PJ, Kleinig TJ, Dewey HM, Churilov L, Yassi N, Yan B, Dowling RJ, Parsons MW, Oxley TJ, Wu TY, Brooks M, Simpson MA, Miteff F, Levi CR, Krause M, Harrington TJ, Faulder KC, Steinfort BS, Priglinger M, Ang T, Scroop R, Barber PA, McGuinness B, Wijeratne T,
Phan TG, Chong W, Chandra RV, Bladin CF, Badve M, Rice H, de Villiers L, Ma H, Desmond PM, Donnan GA, Davis SM; EXTEND-IA Investigators. Endovascular therapy for ischemic stroke with perfusion-imaging selection. N Engl J Med 2015;372:1009-1018.

20. Saver JL, Goyal M, Bonafe A, Diener HC, Levy EI, Pereira VM, Albers GW, Cognard C, Cohen DJ, Hacke W, Jansen O, Jovin TG, Mattle HP, Nogueira RG, Siddiqui AH, Yavagal DR, Baxter BW, Devlin TG, Lopes DK, Reddy VK, du Mesnil de Rochemont R, Singer OC, Jahan R; SWIFT PRIME Investigators. Stent-retriever thrombectomy after intravenous t-PA vs. t-PA alone in stroke. N Engl J Med 2015;372:2285-2295.

21. Powers WJ, Derdeyn CP, Biller J, Coffey CS, Hoh BL, Jauch EC, Johnston KC, Johnston SC, Khalessi AA, Kidwell CS, Meschia JF, Ovbiagele B, Yavagal DR; American Heart Association Stroke Council. 2015 American Heart Association/American Stroke Association Focused Update of the 2013 Guidelines for the Early Management of Patients With Acute Ischemic Stroke Regarding Endovascular Treatment: A Guideline for Healthcare Professionals From the American Heart Association/American Stroke Association. Stroke 2015;46:3020-3035.

22. Verro P, Tanenbaum LN, Borden NM, Sen S, Eshkar N. CT angiography in acute ischemic stroke: preliminary results. Stroke 2002;33:276-278.

23. Mokin M, Masud MW, Dumont TM, Ahmad G, Kass-Hout T, Snyder KV, Hopkins LN, Siddiqui AH, Levy EI. Outcomes in patients with acute ischemic stroke from proximal intracranial vessel occlusion and NIHSS score below 8. J Neurointerv Surg 2014;6:413-417.

24. Heldner MR, Zubler C, Mattle HP, Schroth G, Weck A, Mono ML, Gralla J, Jung S, El-Koussy M, Lüdi R, Yan X, Arnold M, Ozdoba C, Mordasini P, Fischer U. National Institutes of Health stroke scale score and vessel occlusion in 2152 patients with acute ischemic stroke. Stroke 2013;44:1153-1157.

25. Cooray C, Fekete K, Mikulik R, Lees KR, Wahlgren N, Ahmed N. Threshold for NIH stroke scale in predicting vessel occlusion and functional outcome after stroke thrombolysis. Int J Stroke 2015;10:822-829.

26. Vanacker P, Heldner MR, Amiguet M, Faouzi M, Cras P, Ntaios G, Arnold M, Mattle HP, Gralla J, Fischer U, Michel P. Prediction of Large Vessel Occlusions in Acute Stroke: National Institute of Health Stroke Scale Is Hard to Beat. Crit Care Med 2016;44:336-343. 